\title{
ANOTHER NAME FOR THE UMBRELLA BAMBOO
}

\author{
Thomas R. SoDerstrom
}

Soderstrom, Thomas R. (Department of Botany, Smithsonian Institution, Washington, DC 20560). Another name for Umbrella Bamboo. Brittonia 31: 495. 1979.- The new combination Thamnocalamus spathaceus is made.

One of the most popular bamboos in horticulture is the Umbrella Bamboo, a Chinese species native to the mountains of western Hupeh and eastern Szechuan provinces. There the dense clumps three or four meters tall occur in forests of silver fir, birch, maple, and rhododendron at elevations over 2000 meters. Living material collected by Ernest H. Wilson in 1910 was sent to the Arnold Arboretum where it was cultivated and propagules later reached the Royal Botanic Gardens, Kew, England, in 1913. The plants have thrived at Kew in vegetative condition to this day. From these sterile plants in 1920, J. S. Gamble described Arundinaria murielae in honor of Wilson's daughter and designated Wilson 1462 as the type.

For the first time some plants of this species have now begun to flower in Denmark and Germany and material which $I$ have studied indicates that it is not an Arundinaria, as originally described, but rather a species of Thamnocalamus, and is in fact synonymous with a species described earlier as Fargesia spathacea. I have given an historical account of this bamboo in the July-August 1979 issue of GARDEN (vol. 3: 22-27) and below present the new name combination and synonymy.

Thamnocalamus spathaceus (Franchet) Soderstrom, comb. nov.

Fargesia spathacea Franchet, Bull. Mens. Soc. Linn. Paris 2: 1067. 1893. TyPe: CHINA. Szechuan: Dist. Tchen-Kéou-Tin, Farges s.n. (holotype: P; Isotype: US).

Arundinaria sparsiflora Rendle, J. Linn. Soc. Bot. 36: 436. 1904. Thamnocalamus sparsiflorus Keng f., Techn. Bull. Natl. Forest. Res. Bur. 8: 15. 1948. Sinarundinaria sparsiflora Keng f. in Y. L. Keng (ed.), Claves generum et specierum graminearum primarum sinicarum, 153. 1957. TYPE: CHINA. HUPEH: Hsingshan, Henry 6938 (HOLOTYPE: K; ISOTYPE: US).

Arundinaria murielae Gamble in Bean, Bull. Misc. Inform. 10: 344. 1920. Sinarundinaria murielae Nakai, J. Jap. Bot. 11: 1. 1935. Type: CHINA. Western HupeH: Fang Hsien, in 1907 and with description taken from cultivated plants in 1920 at Kew, Wilson 1462 (HOLOTYPE: K). 